\section{SAAAA \\ JOURNAL}

\section{Journal of Archaeology and Fine Arts in Southeast}

Asia

Published by the SEAMEO Regional Centre for Archaeology and Fine Arts (SPAFA)

\title{
The House, The Rice and The Buffalo: Cosmological Perceptions in the Indigenous Architecture of Austronesia
}

Brian Auersbach

Student of Southeast Asian Studies \& Anthropology

Goethe-University Frankfurt

Frankfurt, Germany

b.auersbach@gmail.com

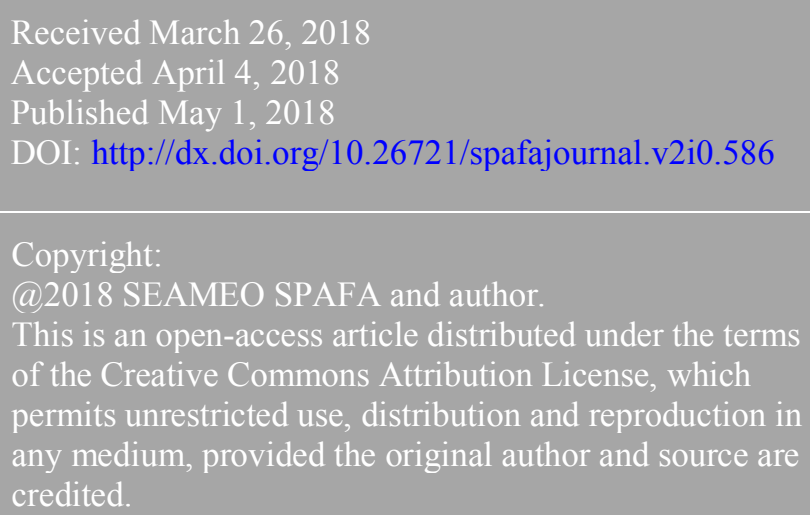

\begin{abstract}
This short article reviews the comprehensive field of study about vernacular architecture in Southeast Asia and the meaning behind these buildings. Cosmological perceptions and animistic beliefs are widespread in Southeast Asia, especially among the numerous tribes in its maritime region of Austronesia. This paper focuses on the connection between indigenous architecture and the cosmological relevance for the inhabitants. Therefore, similar architectural features in Southeast Asia will be elaborated and associated with these consistent cosmological perceptions. Finally, the example of the Toraja people and their story of creation shall illustrate this complex topic.
\end{abstract}

Keywords: Southeast Asia, animism, cosmology, beliefs, indigenous, architecture 
"The space that the house delimits is the first step towards an ordering of the universe." Jacques Dumarçay, 1987

For centuries, the indigenous inhabitants of Southeast Asia have been exposed to the once foreign influences of Islam, Hinduism and to the European colonization. Many cultural assets disappeared or have been mixed since then; language and religion as well as arts and architecture. Nevertheless, many elements with unique characteristics have been preserved, likewise in the vernacular architecture. Some indigenous groups were even able to elude completely foreign influence wherefore we can find numerous iconic traditional buildings in Southeast Asia, especially in the insular region of Austronesia. Austronesia is derived from the Austronesian language family which is widely prevalent in Madagascar, Taiwan, Oceania as well as in maritime Southeast Asia, thus Malaysia and mainly on the islands of Indonesia, where the focus of this article lies. In the following the term Southeast Asia refers to its maritime part Austronesia.

Without taking the well-known and magnificent constructions like Angkor Wat or Borobudur into account, this paper will take a closer look at the supposedly most unspectacular unit of architecture: the indigenous dwelling house. But right here, in the most intimate area of the human being, basic concepts of worldview and cosmology come to light. As much as the various architectural styles differ from island to island and from tribe to tribe, on closer inspection many similarities can be found, both in architecture and in cosmology. In addition to it, these two fields have more in common than we would expect at first sight.

The following paper will focus on exploring the architectural commonalities and their cosmological background in Southeast Asia. Therefore several characteristic construction forms that we can find throughout the archipelago will be emphasized, in particular the pile dwelling and the specific orientation of the house. Furthermore, ornaments will be mentioned since they constitute the most obvious coherence between architecture and indigenous beliefs. Just those beliefs are considered in the second part of this work, because here, too, we will find widely spread similarities in cosmological perceptions. Since the topic is treated for decades and there is a countless number of related literature this paper is more eligible to review the academic field of study, to work out the very basic similarities in the vernacular architecture and to spotlight the deep meanings behind these - supposedly trivial constructions. Finally, the example of the Sa'dan Toraja, an indigenous group in South Sulawesi, and their iconic houses compared with complex stories about the creation of the human being shall illustrate the topic. At this, Roxana Waterson's research on Austronesian architecture (The Living house, 1991) and her ethnography about the Toraja (Paths and Rivers, 2009) form the basic literature for this review.

\section{Common architectural features}

Beside the fact that most vernacular houses are built solely from wooden materials, the most noticeable characteristic that unifies Austronesian houses is the building on stilts. Almost all dwelling houses in the region show this construction form, except a few on Java, Bali and in part on Lombok (Dumarçay 1987: 43). For a post construction multiple piles are fixed in the ground and bear the living space. Although 
the height of the piles can vary widely from place to place, together with the middle level and the roof there is always a discernible tripartite division of the building in a vertical orientation. Beside cosmological reasons, which will be broached later, there are several objective advantages in building a house on piles, especially in the humidtropical climate zone of Southeast Asia. First of all, the available surface can be extended and the lower area becomes suitable as dry storage space and stable for livestock. Moreover, the living area is protected from flooding, crawlers and other vermin, while the open space below the living and sleeping place can also support the ventilation of the house (Jumsai 1997: 83).

A special meaning is given to the main pile. It extends from the ground to the roof and passes its way through all three sections. The main pile is the firstly erected element, mostly as part of a grand inaugural ceremony. Made of one single trunk, the main pile has a fundamental prominence, both for architectural reasons as well as for the inner belief system (Fox 2003: 380).

Another characteristic feature of many Austronesian houses is the saddle-backed roof. Leading up to peaked gables in the front and the back a bending roof is a common occurring attribute, too. A consistent explanation for the meaning of the saddlebacked roof is still missing in the contemporary research but when simply looking at this bent form, the resemblance to a boat is remarkable. Furthermore, the origin of the inhabitants of Southeast Asia as seafaring people must not be ignored. On linguistic examinations some coherences that support this theory were found. Several indigenous groups in Indonesia use seafarer vocabulary like "mast" or "sail" to name parts of their houses or bestow titles like "captain" as well as "steersman" to exalted persons (Arbi 2008: 6-7).

Without any architectural function, ornaments constitute a very important feature of Austronesian houses. On numerous Southeast Asian dwelling houses we can find elaboratively deco-rated facades and gables while the inner room is usually sparsely and practical furnished. Apart from the crested wall paintings the attention in this paper will be drawn to gable ornaments. A highly recurrent feature is the gable-finial in form of buffalo horns, birds or snakes. The buffalo signifies power, prosperity and of course the importance for agriculture. As a working animal it is reared under the house in the lower section and in symbolic opposition to the above living bird which stands for the upper world. Apart from buffalos, the combination of the snake (lower area of life) and the bird is also a quite common ornamental feature in Austronesia, for example at the houses of the Buginese (Sulawesi) or on the island of Halmahera (Waterson 1991: 9). In this connection, perceptions and beliefs about the cosmos and the creation of the world play a role, which will be explained in the following section.

\section{Cosmological ideas in architecture}

Since debating about "cosmology", "animism" or "spiritual beliefs" in general engages the academic disciplines of anthropology, religious and cultural studies for decades, this paper is not entitled to find a common definition of these terms. Instead, we should only keep in mind that "animism [...] admits physical or 'Natural' causation in the form of a naive physics [...], understood as an expression or epiphenomenon of the cosmic or which itself is intentionally constituted" (Århem \& 
Sprenger 2016: 5). Simplified in my own words, animistic beliefs assume a constant coherence between all actions of the human being and its surrounding environment or more specifically its own cosmos. In this context the dwelling house occupies an important place in the cosmos of the indigenous peoples of Southeast Asia.

As already mentioned the material features of the Austronesian house have a specific importance for these cosmological conceptions in Southeast Asia. But not only the material components itself reveal a cosmological order, also the basic orientations of and in the house are liable to distinctive perceptions. Starting with the initially grounding of a house, the directionality of the building is the first aspect that must be scoped out. Although there is no uniform orientation of the Austronesian house, the concept of spatial coordination in a cosmological order is widely spread over the archipelago (Fox 1993: 15). The most common orientation is the connection to the path of the sun. Such as the Atoni house on the island of Timor, where the entrance of the building never faces east or west to avoid the sunlight inside the house. The house is taken to mean as opposition to the sun. The inner cosmos of the house must be separated from external sources of light while it has its own fireplace inside. This fire must be kept alive by the women of the house all time (Waterson 1991: 88). Other similar examples are the houses of the Rotinese on the Indonesian island of Roti (entrance must face north or south) as well as the Sa'dan Toraja house, where the front door is always located north-ward, directed to the head of the river Sa ${ }^{\text {ec }}$ dan in South Sulawesi. In the perception of the Toraja, north signifies the source of life and fertil-ity while going downriver lead to the place of the deceased souls. Apart from the river, the east stands for the sunrise that is con-noted with prosperity and a plentiful harvest, in opposition to the west, "the realm of the setting sun, associated with funeral rituals, which command an extraordinary amount of social activity and material expenditure" (Crystal 1989: 10). An analogical conception can be found at the longhouses of the Iban on Borneo that are aligned to the rivers, while the longitudinal orientation usually is crossed to the path of the sun. Here, too, the sunset in the west relates to death, in contrast to birth and life in the east (Sather 1993: 81). The general distinction be-tween inner - outer, upper - lower, front - back, etc. reflects the idea of a cosmic dualism that can be found in several aspects. Tangible depicted, this dualism occurs commonly in the ornaments of the Austronesian house, wherefore this topic will be revisited below.

\section{Trisection of the house and the cosmos}

While dualistic components usually appear on the horizontal level, we find a significant tri-section mostly in the vertical dimension. As mentioned before, building on stilts is the common characteristic of the Austronesian house and we already know about the pragmatic functions, but at the same time it also reflects an elementary constituent in cosmology. Beginning with the erection of the piles, a clear delimited area below the house floor is created. This space is the most unclean one, reserved for animals, rubbish and kitchen waste. It represents the nether world of the cosmos, which is reserved for lower divinities (Benitez-Johannot 2011: 71). The house floor accommodates the human being and forms the middle world. In a profane environment the daily life takes place here. Located above the substructure and beneath the attic, the middle world builds a connection between lower and upper world. However, the distinction of these "worlds" must not be seen as rigid 
boundaries. Instead it reflects the perception of the indigenous people, their position and participation inside the cosmos and finally the steady interaction with the environment.

The attic is the most sacred part of the house and in connotation with the upper world the sphere of the ancestors and higher deities. In many cases this space is empty (in a profane understanding, that means no functional furniture) or only reserved for heirlooms and ritual items. In addition, some indigenous groups, such as the Atoni on Timor, use the attic also as granary, what emphasizes the importance of agriculture and rice cultivation in particular (Waterson 1991: 174). Worshipping of rice especially comes clear by looking at the granaries of the Toraja. Although they do not store their rice within the dwelling house, however, the rice granaries are exact afterimages of the houses, including dualistic roof construction and trisection (building of stilts), that places the rice above the middle level of the human being into the upper world. Since the granaries are also oriented to the north in front of the houses $^{\text {ee }}$ entrance door, worshipping of rice is liable to a cosmological order, obviously clarified in the structure of vernacular architecture (Crystal 1989: 11)

To keep to the point of holy components of the Austronesian dwelling house another central element must be mentioned: the main pillar. For instance, in the inaugural rite of an Iban long-house construction the central main post is ,,bathed ${ }^{\text {ee }}$, scattered with rice and rubbed with the blood of a sacrificed chicken. Since the clue is in the name, the main pillar has a very practical but also important function of conferring stability. But in the cosmological view of the indigenous people of Southeast Asia the central post of the house is given a much deeper meaning. In most cases it is the first erected part of the building. A common perception is that the main pillar must be "planted". The main pillar, often called the "navel" or "guardian" of the house, should be made of one single trunk and erected with its former root side end down. In earlier headhunting societies, especially on Borneo, human bodies were offered and buried in the post hole (Waterson 1991: $123 \mathrm{f}$.). The main pillar breathes life into the house and forms the consistent connection from the lower to the upper world. Beside the static function it gives steadiness to the cosmological order for the inhabitants and their environment. The house as a whole is often associated with the so-called Tree of Life. For example, the Iban longhouse, which also has several main pillars, each for one family apartment, possesses one special main post, which is the first erected component and the symbolic source of life for the house. In the perception of the Iban, the roots of the piles are connoted with origin and entrenchment with the soil. The trunk refers to the middle world inhabited by the human being and is connected to the treetop as upper world (Sather 1993: 77).

\section{Gable ornaments of the Austronesian house}

One of the most remarkable features of the Austronesian house are the gable ornaments or comparable components at the entrance side. Crossed finals at the peak of the roof, swords as well as mythical animals or buffalo horns above the entrance; the variation is broad, but all these decorations share the background of cosmological perceptions. The buffalo as decorative element can be found on the islands of Sumatra (Batak), Sumba (Sumbanese) or Sulawesi (Toraja) and many more. This shows the great importance for agriculture on one hand, but also the mythical beliefs behind this 
strong animal. It is a symbol for wealth, prosperity and often has a sacrificial and protective role. Several people, among them the Mandailing on Sumatra, connect the buffalo with death and afterlife, since it is used as carrier for the de-ceased souls to the upper world (Waterson 1991: 7-8).

Further animalistic ornaments can figure birds and snakes. Mythical birds are connoted as members of the upper world and serve as auxiliaries as well as carriers of the higher deities. In opposition, the snake as entity of the lower world represents the symbol for the primeval sea as part of several indigenous creation myths. The holy fight between these two animals, the bird from the upper world and the snake from the lower world, is believed to result in the creation of the middle world and finally of the human being. Regarding to a mythical snake, there is usually the talk of Naga, a chimera that originally found its way from Hinduism into the indigenous beliefs of Southeast Asia. The counterpart of Naga is the mythical bird Garuda, also an actual Hindu figure that can take the shape of a falcon or hornbill. Other architectural decorations can be a plough shape, again to emphasize the importance of agriculture, as well as a rudder, which mainly can be found on Sumatra and refers to the maritime origin of the Southeast Asian people. But nevertheless, the horn-shaped buffalo gable, the bird and the Naga ornaments remain the most common and obvious decoration features of Austronesian dwelling houses (Jumsai 1997: 136).

\section{The Sa'dan Toraja House and their Story of Creation}

The Sa'dan Toraja are an indigenous group living in Tanah Toraja in the South of the Indonesian island of Sulawesi. Since their territory in the highlands is rather secluded, the Toraja culture and their animistic belief system have hardly changed. Also, most of their impressive house construction forms with all the previously mentioned characteristics still exist and constitute a paragon for the indigenous architecture of Southeast Asia. In conclusion the Sa'dan Toraja house illustrates all consistent architectural features: the cardinal orientation to the environment (in this case to the river Sa'dan northwards) and the path of the sun, the trisection trough building on stilts, a well-marked saddle-backed roof finalized by gable ornaments mostly in the form of a bird as well as buffalo horns in the entrance area.

There is a close relation of the Toraja house and their various Stories of Creation. Already in the early 1950s and later in 1965, accompanied by Henrik van der Veen, Hetty NooyPalm composed a detailed ethnography about the Toraja and their cosmological beliefs (Nooy-Palm 1979). Subsequently, Roxana Waterson associated these mythical beliefs with the characteristic architecture of the Toraja in her broad academic work (Waterson 1991 \& 2009). The following tale from Ke'te Kesu', a famous Toraja village in South Sulawesi, is only one among many more, since oral traditions varied and can differ from place to place, even within an ethnic group (Waterson 2009: 127).

In the beginning of the Toraja cosmos there was chaos. The sky and the earth were still lying on top of each other. But finally, heaven and earth separated and gave rise to a lot of space on earth. Out of the union of heaven and earth came three children: Pong Banggairante, the god of the earth, Pong Tulakpadang, god of the lower world who carries the world shoulder high, and finally the higher world god Gauntikembong. He created Usuk Sangbamban out of one of his ribs (the influence here of Christianity or Islam is disputed; Nooy-Palm 1979: 135). Usuk Sangbamban 
married Lokkon Loerara, a woman made from a rock. From this marriage Puang Matua, the 'Old Lord' and one of the main deities of the Toraja, was born.

Puang Matua married the goddess Arrang di Batu ('Light from the Stone') and was sent by his wife westward to search for gold (referring to really existing gold mines in Bittuang, South Sulawesi). When Puang Matua finally found the gold and began to melt it, he created the first human being, Datu Laukku, out of his forge-bellows. Datu Laukku got seven more siblings, which, like him, also arose from the same divine bellows. One of them was Kam-bunolangi', who has the well-respected status of a demigod, while on the other hand two of his siblings became the first slaves on earth. The other four siblings helped Puang Matua to build an iron house in the middle of the sky, the prototype of the first dwelling houses later on earth. Also, the first sawah, a wet paddy field, was created. However, the rice did not want to grow at the very beginning. Therefore, two creatures were born, Datu Mengkamma' and Karaeng Ma'loko-loko, the first rice priests, who finally made the rice to thrive. Furthermore, Puang Matua assigned the buffalo for the most important ritual animal (Nooy-Palm 1979: $136 \mathrm{ff}$.). The early mentioning of the house, the rice and the buffalo in the Story of Creation clarifies the importance of these three things in the everyday world of the Toraja.

Puang Matua's first house resembled the simple shelters later on earth. But he wanted to cre-ate an unruinable house on iron posts and timber from a tree with seven branches and seven leaves. Unfortunately, this house slid into a deep pond and for appeasing the gods to recover the house offerings had been made. In this rite, that is what the myths tell, the posts were festive decorated. Today, this ritual is still practised during the erection of the main "navel" post.

There are many myths about the first carpenters. Stories from the region of Sinaji in South Sulawesi tell about the four carpenters Pong Kaekae, Pong Lellesu', Pong Kalolok and Pong Sabannangna. Their construction constituted the prototype of all tongkonan, the traditional ancestral house of the Toraja. Already the first house had the significant characteristics of a saddle-backed roof and decorative carvings. Pong Kalolok was a human shaped tree and re-sponsible for the worked wood. He did not need any help and could simply stretch the timber to the right size. The other three carpenters began to feel useless and became jealous of Pong Kalolok. Finally, they murdered him and he transmuted to carpenter bees and termites. This short part of the story reveals the important meaning of the environment and the wide-spread perception of an ensoulment of the nature (Waterson 2009: $135 \mathrm{f}$.)

\section{Conclusion}

This rough story of the Toraja and their iconic dwelling houses shall underline how cosmological perceptions are closely related to the vernacular architecture in Southeast Asia. For most of the indigenous Austronesian inhabitants, the house stands for their own micro cosmos within a larger cosmos that is filigreed with so many perceptions and beliefs. Animistic and cosmological views as well as the many Stories of Creation in Southeast Asia are complex and hardly to elaborate in a short article like this. Nevertheless, this previous review of a decades-long research by several venerable field workers is an approach to recollect a research area that is still 
rich in content. In our fast-paced times of globalization, urbanization and rural exodus, we should wake up to the fact that the simple appearing dwelling houses of Southeast Asia are representing deep-seated traditions, sophisticated belief systems and identity-establishing constructions, both in material, tangible buildings as well as abstract images of ordering the indigenous social structures.

\section{References}

Adams, KM (1998) More than an Ethnic Marker: Toraja Art as Identity Negotiator. American Ethnologist 25(3): 327-351. Crossref

Arbi, E (2008) Austronesian vernacular Architecture and the Ise Shrine of Japan: Is there any Connection? Journal of Design and Built Environment 4(1): 15-21. Google Scholar Search

Århem, K and Sprenger, G (eds.) (2015) Animism in Southeast Asia. London: Routledge. Crossref

Benitez-Johannot, P (2011) Paths of Origins. The Austronesian Heritage. Makati City: Artpostasia. Google Scholar Search

Crystal, E (1989) Myth, Symbol and Function of the Toraja House. Traditional Dwellings and Settlements Review 1(1): 7-17. Google Scholar Search

Dumarçay, J (1987) The House in South-East Asia. South Melbourne: OUP Australia \& New Zealand. Google Scholar Search

Fox, JJ (1993) Comparative Perspectives on Austronesian Houses: An Introductory Essay. In: JJ Fox (ed.) Inside Austronesian Houses: Perspectives on domestic Designs for Living. Canberra: ANU Press, 1-30. Google Scholar Search

Fox, JJ (2003) Perpetuating Ancestral Foundations. Some Transformations of Austronesian Houses. In: R Schefold and D Gaudenz and P Nas (eds.) Indonesian houses: Tradition and Transformation in vernacular Architecture. Leiden: KITLV Press, 369-388. Google Scholar Search

Jumsai, S (1997) Naga: Cultural Origins in Siam and the West Pacific. Bangkok: Chalermnit Press and DD Books. Google Scholar Search

Nooy-Palm, H (1979) The Sa'dan Toraja: A Study of their social Life and Religion. Leiden: KITLV. Google Scholar Search

Sather, C (1993) Posts, Hearths and Thresholds: The Iban Longhouse as a Ritual Structure. In: Fox, JJ (ed.) Inside Austronesian Houses: Perspectives on domestic Designs for Living. Canberra: ANU Press, 67-120. Google Scholar Search

Waterson, R (1991) The Living House: An Anthropology of Architecture in SouthEast Asia. Singapore: Oxford University Press. Google Scholar Search

Waterson, R (2009) Paths and Rivers: Sa'dan Toraja Society in Transformation. Leiden: Brill. Crossref

Wessing, R (2006) Symbolic Animals in the Land between the Waters. Markers of Place and Transition. Asian Folklore Studies 65(2): 205-239. Google Scholar Search 